\title{
EFFECT OF MID DAY MEAL PROGRAMME ON THE NUTRITIONAL
}

\section{STATUS OF SCHOOL CHILDREN}

\section{CHETHANA \& ARCHANA PRABHAT}

Department of Food Science and Nutrition, Alva's Centre for Post Graduate Studies and Research,

Moodbidri, Karnataka, India

\begin{abstract}
Mid-day meal scheme is one of the important policies and the main purpose of it is to lower the cost of schooling and also to improve the nutritional level of children. School going children are vulnerable to malnutrition and nutritional deficiencies having a negative effect on the growth and development of children.

OBJECTIVE

To assess the effect of Mid-day meal on the nutritional status of school going children (6-12 years).

\section{METHODOLOGY}

It was a cross-sectional study done on sixty children having regular Mid-day meal. Anthropometric assessment i. e., Height, Weight, Mid Upper arm circumference (MUAC) were done and compared with ICMR standard values. Daily dietary intake and food consumption pattern were studied for three consecutive days.

RESULTS

The study showed that the mean height and weight of school children were considerably lower than the ICMR standards but mid-upper circumference value found to be similar to that of standards irrespective of consuming regularly the mid-day meal provided at their institutions. From the diet recall method, it was understood that mean micronutrient intake was unsoundly lower than the standard recommendations.

\section{CONCLUSIONS}

Mid-day meal programme has a very low effect on the nutritional status of the subjects and requires a better modulation in providing the variety of the foods with required essential nutrients proportion for the sustainability of health during the growth period of the school going children.

KEYWORDS: Mid Day Meal Programme, Malnutrition, Anthropometric Measurements, Dietary Intake \& Nutritional Status
\end{abstract}

Received: Aug 20, 2018; Accepted: Sep 10, 2018; Published: Sep 27, 2018; Paper Id.: IJEEFUSOCT20185

\section{INTRODUCTION}

\section{Mid Day Meal Programme}

According to the constitution of India, all the children have the right to get primary education. Although it of not hundred percent successes, it has shown up a constant tremendous developing. Hence Government has put forward an amendment to enroll the maximum number of students from the age group of $6-12$ years for free education [1]. The Mid Day Meal Scheme is a multi-purpose programme of the Government 
of India that, to address issues of food security, lack of nutrition and access to education [2]. This Scheme was launched in the year 1995 August $15^{\text {th }}$ in nationwide by the Department of Elementary Education and Literacy, Ministry of Human Resources Development, Government of India. In the year 2002, this scheme was extended to cover the children studying in Education Guarantee Scheme (EGS) and Alternative Informal Education (AIE). In September 2002, an attempt was made to revise the mid-day meal scheme providing 300 kilocalories and 8-12 grams of protein respectively to all students of class I-V both government and government-aided schools. With all that fruitful results, Scheme was extended to the upper primary classes (VI to VII) in the year October 2007[3]. It provides free lunch on working days both for Primary and Upper Primary classes. This scheme is the largest school lunch programme in India with an eloquent objective to provide the nutritional support for school children in both rural and urban areas [4]

Primary school age is a dynamic period of physical growth and mental development of the children [5]. Children contribute to the vital human potential and they are the strength to the nation's economy and development. During this period, very importantly the need for nutrition is mandatory as it is a determinant of health, labor productivity and mental development [6] Their Nutritional status and Health are monitored for the betterment of learning, maturation and also physical developments [7]. Physical growth of children is reflected by their anthropometric measurements especially weight and height. On the other hand, child height and weight is the efficient tool for recognition of their nutritional status [8]

\section{Malnutrition}

Malnutrition in children is multidimensional, governed by biological, behavioral and environmental factors. It places a huge burden by not only increasing mortality but also improves significant national health and development costs due to associated morbidities, including reduced cognitive ability. It reduces children's resistance to infection and increases the burden of disease in the communities. Poor nutrition is one of the greatest problems in rural India, resulting from faulty dietary habits, poor immune system and causes a significant growth delay. The country is still struggling with these issues. Many factors can cause malnutrition, inadequate food intake, infections, psychosocial deprivation, insanitary environment, social inequality, lack of hygiene and some genetic contribution.

\section{Prevalence}

Malnutrition indicates that children are either too short for their age or too thin. India's performance on key malnutrition indicators is poor according to national and international studies. According to UNICEF, India was at the 10tn spot among countries with the highest number of underweight children, and at the $17^{\text {th }}$ spot for the highest number of stunted children in the world. The WHO estimates that malnutrition accounts for 54\% of child mortality worldwide, childhood underweight accounts for 35\% of all death worldwide. In developing countries, $52 \%$ are stunted and $34 \%$ to $62 \%$ are underweight [11].

\section{METHODOLOGY}

\section{Selection of Subjects}

57 subjects were selected for the study. Random sampling was done for the selection with 29 boys and 28 girls. The purpose of the selection of subjects was explained briefly to the students. 


\section{Study Area}

The study was carried out in Government higher primary school, Mukkur Peruvaje, Bellare cluster, Sullia Taluk.

D. K

\section{Collection of Data}

\section{Demographic Data}

Once subjects were selected, their demographic data were collected using structured Questionnaire.

A pre-tested questionnaire was given which include age, gender, family history, occupation and education of the parents, family size, SES and food preferences were elicited.

\section{Anthropometric Assessment}

Assessment of anthropometric measurements includes Height, Weight, and mid-upper arm circumference. Then mean values are compared with ICMR standards.

\section{Height and Weight}

The height of the subjects was measured using height measuring scale. Then the weight of the individual was measured using a weighing machine. Recorded height and weight was compared with Standard values.

Standard height and weight for boys and girls are represented in the tabular form:

Table 1: ICMR Standard Height and Weight for Boys

\begin{tabular}{|c|c|c|c|c|}
\hline & \multicolumn{2}{|c|}{ Boys } & \multicolumn{2}{c|}{ Girls } \\
\hline $\begin{array}{c}\text { Age } \\
\text { (years) }\end{array}$ & $\begin{array}{c}\text { Weight } \\
(\mathbf{k g})\end{array}$ & $\begin{array}{c}\text { Height } \\
(\mathbf{c m})\end{array}$ & $\begin{array}{c}\text { Weight } \\
(\mathbf{k g})\end{array}$ & $\begin{array}{c}\text { Height } \\
(\mathbf{c m})\end{array}$ \\
\hline 6 & 20 & 116 & 19 & 114 \\
\hline 7 & 23 & 121 & 21 & 120 \\
\hline 8 & 25 & 127 & 24 & 126 \\
\hline 9 & 28 & 132 & 28 & 132 \\
\hline 10 & 31 & 137 & 32 & 138 \\
\hline 11 & 32 & 140 & 33 & 142 \\
\hline 12 & 37 & 147 & 38 & 148 \\
\hline
\end{tabular}

\section{Mid-Upper Arm Circumference}

Mid-upper arm circumference of the individual was measured using a measuring tape and compared with standard mid-upper arm circumference value according to age.

Table 2: Standard Mid Upper Arm Circumference

\begin{tabular}{|c|l|}
\hline MUAC Range & \multicolumn{1}{|c|}{ Malnutrition Status } \\
\hline$<11.0 \mathrm{~cm}$ & Severe malnutrition \\
\hline $11.0 \mathrm{~cm}$ to $12.5 \mathrm{~cm}$ & Moderate malnutrition \\
\hline $12.5 \mathrm{~cm}$ to $13.5 \mathrm{~cm}$ & Acute malnutrition \\
\hline$>13.5 \mathrm{~cm}$ & Well nourished \\
\hline
\end{tabular}

Information on meal pattern was collected by following 24 hours recall method of diet survey for 3 consecutive days. The recall included each and every food that consumed in 3days of time. The adequacy of foods and nutrients of diet consumed was calculated and compared with actual requirements and recommended dietary allowances. 
During the collection of diet history, it was mandatory to understand the inclusion of food Stuff contributing the nutrients in mid-day meal; so that to analyze the essential nutrients required for the normal growth and development.

Table 3: Quantity of the Food Items Used in the Midday Meal

\begin{tabular}{|l|c|c|}
\hline \multicolumn{1}{|c|}{ Item } & Primary & Upper Primary \\
\hline Rice & $100 \mathrm{gms}$ & $150 \mathrm{gms}$ \\
\hline Pulses & $20 \mathrm{gms}$ & $30 \mathrm{gms}$ \\
\hline Vegetables & $50 \mathrm{gms}$ & $75 \mathrm{gms}$ \\
\hline Oil & $5 \mathrm{gms}$ & $7.5 \mathrm{gms}$ \\
\hline Salt & $2 \mathrm{gms}$ & $2.5 \mathrm{gms}$ \\
\hline \multirow{2}{*}{ Micronutrients } & $\begin{array}{l}\text { Adequate other micronutrients like } \\
\text { Iron, Folic acid, Vitamin A etc. }\end{array}$ \\
\hline
\end{tabular}

The oral questionnaire consisted of the questions related to food frequency, likes and dislikes of foods, amount of water consumed in a day, the taste of mid day meal, quality and quantity of midday meal, variety and over all acceptance of midday meal. Once complete data is obtained then it was statistically analyzed with the help of percentage, mean and standard deviation, analysis and t-test.

\section{RESULTS AND DISCUSSIONS}

Table 4 presents the mean height of the selected subjects. As per the standard heights are concerned the mean height of the study population was found to be very low, it is due to the fact that as it is growing period and in turn required intake may not be able to meet the requirement. But as they enter into the early adolescent (above 10years), there was an appreciable increase in the height to the standard value.

Table 4: Mean Height of Selected Subjects

\begin{tabular}{|c|c|c|c|c|c|c|c|c|}
\hline \multicolumn{4}{|c|}{ Boys } & \multicolumn{4}{c|}{ Girls } \\
\hline $\begin{array}{c}\text { Age in } \\
\text { Years }\end{array}$ & $\begin{array}{c}\text { No. of } \\
\text { Children }\end{array}$ & Height (cm) & $\begin{array}{c}\text { Mean Height } \\
\text { \& S. D } \pm\end{array}$ & $\mathbf{p ~ V a l u e ~}$ & $\begin{array}{c}\text { No. of } \\
\text { Children }\end{array}$ & $\begin{array}{c}\text { Height } \\
(\mathbf{c m})\end{array}$ & $\begin{array}{c}\text { Mean Height } \\
\text { \& S. D } \pm\end{array}$ & p Value \\
\hline 6 & 2 & 116 & $\begin{array}{c}113 \\
\pm 1.41\end{array}$ & 0.024 & 5 & 114 & $\begin{array}{c}112.6 \\
\pm 2.19\end{array}$ & 0.374 \\
\hline 7 & 3 & 121 & $\begin{array}{c}114 \\
\pm 2.64\end{array}$ & 0.423 & 4 & 120 & $112.25 \pm 0.95$ & NS \\
\hline 8 & 5 & 127 & $\begin{array}{c}116.6 \\
\pm 3.36\end{array}$ & 0.587 & 2 & 126 & $\begin{array}{c}117 \\
\pm 5.65\end{array}$ & 0.205 \\
\hline 9 & 3 & 132 & $\begin{array}{c}121 \\
\pm 4.35\end{array}$ & 0.289 & 4 & 132 & $\begin{array}{c}119.25 \\
\pm 4.19\end{array}$ & 0.133 \\
\hline 10 & 9 & 137 & $\begin{array}{c}126 \\
\pm 6.13\end{array}$ & 0.026 & 1 & 138 & $\begin{array}{c}112 \\
0\end{array}$ & NS \\
\hline 11 & 2 & 140 & $\begin{array}{c}136 \\
\pm 6.36\end{array}$ & NS & 2 & 142 & $\begin{array}{c}129.5 \\
\pm 0.707\end{array}$ & 0.126 \\
\hline 12 & 5 & 147 & $\begin{array}{c}141.8 \\
\pm 8.78\end{array}$ & 0.426 & 11 & 148 & $\begin{array}{c}136.2 \\
\pm 6.21\end{array}$ & 0.007 \\
\hline
\end{tabular}

NS-Non significant; 0.00 Highly significant

A perusable of table.5 shows the mean weight of the selected subjects. Once again the mean weight was found to be comfortably low to the standard. As per the statistical analysis, my observation strategy as got the association with statistical analyzes that are boys have attained their growth in early adolescents compared to their low counterparts. 
Table 5: Mean Weight of Selected Subjects

\begin{tabular}{|c|c|c|c|c|c|c|c|c|}
\hline & \multicolumn{4}{|c|}{ Boys } & \multicolumn{4}{c|}{ Girls } \\
\hline $\begin{array}{c}\text { Age in } \\
\text { years }\end{array}$ & $\begin{array}{c}\text { No. of } \\
\text { children }\end{array}$ & $\begin{array}{c}\text { Weight } \\
(\mathbf{k g})\end{array}$ & $\begin{array}{c}\text { Mean weight } \\
\text { S. D } \pm\end{array}$ & p value & $\begin{array}{c}\text { No. of } \\
\text { children }\end{array}$ & $\begin{array}{c}\text { Weight } \\
(\mathbf{k g})\end{array}$ & $\begin{array}{c}\text { Mean } \\
\text { weight S. } \\
\text { D } \pm\end{array}$ & p value \\
\hline 6 & 2 & 20 & $\begin{array}{c}17 \\
\pm 1.41\end{array}$ & 0.5 & 5 & 19 & $\begin{array}{c}16.8 \\
\pm 3.193\end{array}$ & 0.089 \\
\hline 7 & 3 & 23 & $\begin{array}{c}17.33 \\
\pm 3.21\end{array}$ & 0.118 & 4 & 21 & $\begin{array}{c}16.75 \\
\pm 1.258\end{array}$ & 0.0215 \\
\hline 8 & 5 & 25 & $\begin{array}{c}20.6 \\
\pm 3.28\end{array}$ & 0.099 & 2 & 24 & $\begin{array}{c}17.5 \\
\pm 2.12\end{array}$ & 0.5 \\
\hline 10 & 3 & 28 & $\begin{array}{c}23.7 \\
\pm 4.16\end{array}$ & 0.691 & 4 & 28 & $\begin{array}{c}23.25 \\
\pm 2.98\end{array}$ & 0.342 \\
\hline 11 & 2 & 32 & $\begin{array}{c}25.2 \\
\pm 2.77\end{array}$ & 0.753 & 1 & 32 & $\begin{array}{c}24 \\
0\end{array}$ & NS \\
\hline 12 & 5 & 37 & $\begin{array}{c}31.2 \\
\pm 6.14\end{array}$ & 0.028 & 11 & 38 & $\begin{array}{c}31.3 \\
\pm 4.73\end{array}$ & 0.05 \\
\hline
\end{tabular}

NS-non significant; 0.0 significant

Nutritional status of the selected subjects is presented in the table 9. 92\% Almost half of the study population are well nourished [13].

Table 6: Percentage of MUAC of the Selected Subjects

\begin{tabular}{|c|c|}
\hline $\begin{array}{c}\text { Mid Upper Arm } \\
\text { Circumference } \\
\text { (MUAC) }\end{array}$ & $\begin{array}{c}\text { Number of Children } \\
(\%)\end{array}$ \\
\hline$<11.0 \mathrm{~cm}$ & $1(2 \%)$ \\
\hline $11.0 \mathrm{~cm}-12.5 \mathrm{~cm}$ & $1(2 \%)$ \\
\hline $12.5 \mathrm{~cm}-13.5 \mathrm{~cm})$ & $2(4 \%)$ \\
\hline$>13.5 \mathrm{~cm})$ & $53(92 \%)$ \\
\hline
\end{tabular}

Graphical representation (Figure 1) clearly highlights their dietary intake. In the study fats and oils were exclusively used in the diet and bound to expect as there is a craving towards fatty foods. Regular intake of fruits and vegetables is only $50 \%$ of the requirements. Beyond the recommendations, the food groups like cereal and sugar found to be around $16 \%$ and $33 \%$.

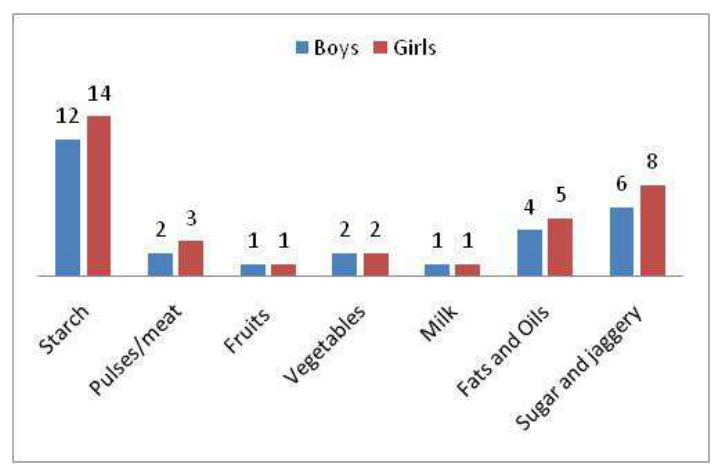

Figure 1: Dietary Intake of the Selected Subjects

Mean macronutrient of the standard and the actual intake was compared and presented in the graph. None of the essential nutrients are meeting with requirements. The adequacy of requirement as then following shot with 
energy with only $71 \%$ followed by protein and fat respectively (49\% and 27$)$.

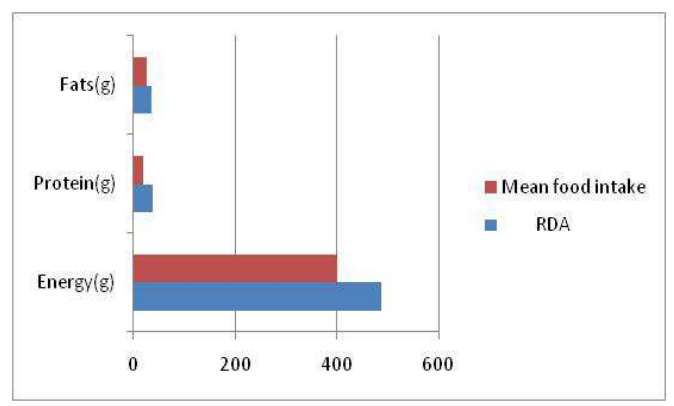

Figure 2: Comparison of Macronutrients (Standard v/s Actual))

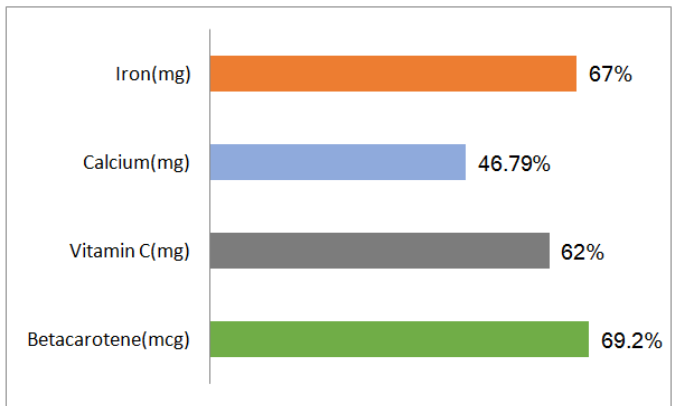

Figure 3: Micronutrients

Figure 3 Illustrates the Micronutrient Intake The essential nutrients like beta-carotene, Vitamin C, Calcium, and Iron helps into concern as then highly important during the growing period [14]. As studies show that they should be beyond the supply of all the essential nutrients in order to keep up the standard requirements for the normal growth. It was very astonishing to note that there is a huge requirement needed for the normal growth and development. $80 \%$, almost three-fourths of the iron id not met and $60-65 \%$ is what they were running shot of Vitamin A and Vitamin C. $45 \%$ of calcium as not been met for the normal growth metabolic functions.

The perusal of table 7 gives the details pf calorie and Protein gained from midday meal programme for the study population. It is been well distributed as per the growth stage of the subjects.

Table 7: Contribution of Calorie and Protein from Midday Meal

\begin{tabular}{|c|c|c|c|c|}
\hline & \multicolumn{2}{|c|}{ Lower Primary } & \multicolumn{2}{c|}{ Higher Primary } \\
\hline Food Stuffs & Calorie(kcal) & Protein(g) & Calorie(kcal) & Protein(g) \\
\hline Rice & 345 & 6.8 & 517.5 & 10 \\
\hline Dhal & 65 & 5 & 81.25 & 7.5 \\
\hline DF Salt & 27 & 0 & 54 & 0 \\
\hline Oil & 54 & 0 & 54 & 0 \\
\hline Vegetables & 54 & 2 & 75.6 & 3 \\
\hline Total & 491 & 13.8 & 728.35 & 20.5 \\
\hline
\end{tabular}

Figure 4 shows the column graph presents the subject's response to the midday meal as per the level of satisfaction. The parameters like quantity and variety have the satisfaction. The quality and taste have a kind of discrimination which where are the range of $5 \%$ to $15 \%$. The overall acceptability was $47 \%$. 


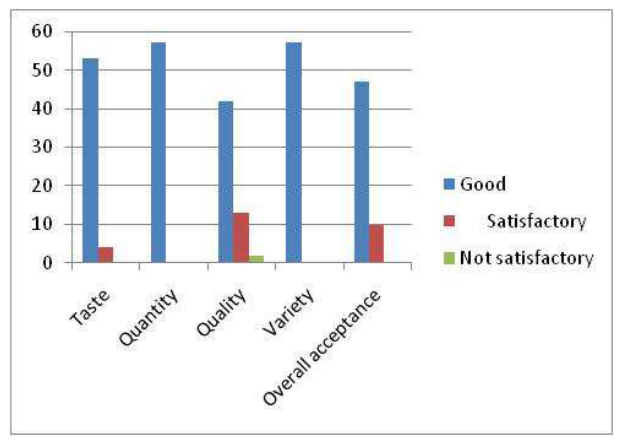

Figure 4: Response to the Mid Day Meal

The pie charts (figure $5 \mathrm{a}$ and $5 \mathrm{~b}$ ) has a comparison on attendance and the health condition of the subjects. It clearly depicts that $96 \%$ of the study subjects were regular in attendance. My findings support the studies where it meets the strong association between midday meal and attendance and invariably $98 \%$ of them had an excellent health condition. This shows that one third of the daily requirement with a profound contribution of essential nutrients can be preferable for the growth and development during the growth period (6-12years) [15].

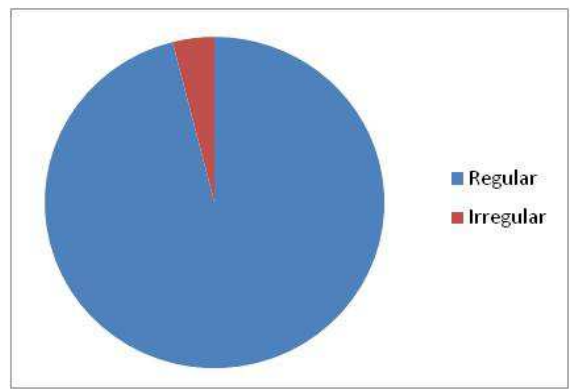

Figure 5a: Attendance of the Subjects

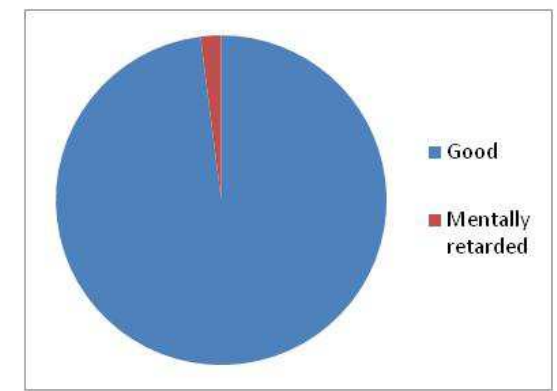

Figure 5b: Health Condition of Subjects

\section{CONCLUSIONS}

The Mid-day Meal Scheme in India is the largest school meal programme in the world, covering an estimated 139 million children. It also has the largest child development programme (the Integrated Child Development Services or ICDS), which provides free meals to the school children as a part of the nutritional programme. MDMS Scheme was initiated to improve enrolment and attendance of primary school children, while simultaneously improving their nutritional status. mid Day Meal Scheme had proved to be effective to check dropout rates of children from the low economic background, and also addressing their nutritional needs.

Nutrition Support to Primary Education popularly referred to as mid Day Meal programme (MDM) is considered as a means of promoting improved enrolment, school attendance, and retention. MDM was providing for each school child roughly one-third of the daily nutrient requirement in the form of a hot cooked meal. It was better for some children from poor households; the school meal may become a substitute rather than a supplement for the home meal. It was important to note that it was not merely the long-term effects of the school meal on the nutritional status but its Short-Term Effects on better attention, memory and learning capacity. A hungry child is a poor learner and lack of concentration. A midday meal was an important instrument for combating classroom hunger and promoting better learning. Many children reach school with an empty stomach in the morning. Children from all castes and communities eating together, was also an instrument to bring better social integration. 
The study was carried out with the objective of the effect of midday meal on the nutritional status and attendance of school going children. Anthropometric assessment was carried out. Some structured questionnaires were also used at the time of data collection which includes demographic details of individual student and diet recall for three consecutive days. During the collection of the data main aspects like enrolment, attendance and information about the quality, taste, quantity of mid-day meal were taken; Further statistics was used for in-depth analysis and in order to obtain the degree of relationship of selected variables in the study.

The study concludes that the nutritional status of children was low mainly because of the economic status and other demographic aspects like the occupation of the father, education of parents and hereditary history. But mid-day meal provides sufficient nutrients and about one-third of the total recommended calories and meets the nutritional requirement during the lunchtime. The attendance rate of children was extremely high and it is strongly associated with midday meal. As per my opinion, there is a need for nutritional education to growing children and their mothers. So that they can inculcate the use of commonly and easily available low cost food which invariably spikes the nutrient composition of the prepared meal. Hence their growth and development can be sufficiently met.

\section{ACKNOWLEDGEMENT}

Special acknowledgement to all the participants for their kind cooperation during the data collection.

\section{REFERENCES}

1. Mansukhlal, J. K. (2012). A Study of Effectiveness of the Mid Day Meal Scheme Implemented In Primary Education. Singhania University Pacheri Bari, Jhunjhunu(Raj.), India, 1-10.

2. Karunakaran, K. T. (2015). Impact Of Mid-Day-Meal-Scheme (Mdms) On Nutritinal Level, Enrolment Rate And Dropout Rate Of School Children In Kerala: A Case Study. Journal of Economic \& Social Development, 1-5.

3. Mehta, B. K. (2013). Nutritional Contribution Of Mid Day Meal To Dietary Intake Of School Children In Ludhiana District Of Panjab. Journal of Nutrition Food Science, 1-183.

4. Cynthia, S. (2015). Nutritional Status Of Government Primary School Children In An Urban Kurnool, Andhra Pradesh. International Journal of Current Medical and Applied Sciences, 167-170.

5. Yadav, P. a. (2014). Nutrition Adequacy Of Mid Day Meal In Allahabad Schools. Asian Journal of Home Science, 655-657.

6. Kulshrestha, K. a. (2011). A Study Of Mid Day Meal Scheme And Its Impact On Health Of Primary Classes (6 To 11 Yrs) In Meerut Region (Uttar Pradesh). Food Science Research Journal, 122-124.

7. Sushma tripathi, A. C. (2013). Assessment Of Height, Weight And BMI Of School Going Children In Varanasi. Asian Journal of Home Science, 496-498.

8. Sintayehu Hailu, M. W. (2016). Iodine Deficiency And Associated Factors Among School Children:A Cross Sectional Study In Ethiopia. The official journal of the Belgian Public Health Association, 1-46.

9. Wafaa Y. Abdel Wahed, S. K. (2017). Malnutrition and Its Associated Factors among Rural School Children in Fayoum Governorate Egypt. Journal of Environmental and Public Health, 1-9.

10. Palanisamy Navaneethan, T. K., \& Chandrasekaran Rajasekaran, N. S. (2011). Nutritional Status Of Children In Rural India: A Case Study. doi:10.4236/health.2011.310109, 647-655. 
11. Nutan, P. (2014). To Assess the Nutritional Status of the Midday meal consuming rural School Going girls(7-10years). International Journal of Engineering Science Invention, 31-33.

12. Maity, B. (2015). Nutritional Status Of School Children In Rural Scenario. Journal of Economic \& Social Development, 5665.

13. Anurag Srivastava, S. E. (2012). Nutritional Status Of School-Age Children-A Scenario Of Urban Slums In India. The official journal of the Belgian Public Health Association, 1-8.

14. Navali. L, K. M. (1992). The Study Of Weight And Height In Children Of Theran. Shahaeed Behesthi Univ. Sci., J. Fac, $18-27$.

15. De Onis. M, H. (1996). Anthropometric Reference Data For International Use: Recommendations From A World Health Organization Expert Committee. The American Journal of Clinical Nutrition, 650-658.

16. Abudayya. A, T. A. (2007). Overweight, stunting, and anemia are public health problems among low socioeconomic groups in school adolescents (12-15 years) in the North Gaza Strip. Nutrition Research, 762-771.

17. Meda, P., \& Kamalaja, T. Assessment Of Nutritional Status And Menarcheal Age Of Rural Adolescent Girls. 
